\title{
DE VENTAS Y VENTEROS: TRADICIÓN LITERARIA, IDEOLOGIA Y MIMESIS EN LA OBRA DE CERVANTES
}

La literatura culta castellana del Siglo de Oro se nutrió de una extensa y variada tradición oral de carácter folklórico, desconocida o menospreciada durante años por la crítica, y que recientemente se ha empezado a descubrir y recoger; de manera que allí donde la erudición académica trataba de adivinar hasta hace muy poco la huella libresca o la paráfrasis del texto griego o latino, hoy percibimos la presencia cierta del refrán, la conseja, el cuentecillo, o el personaje tópico forjado por la mentalidad popular ${ }^{1}$.

I Veanse especialmente los trabajos de MAXIMe CHevalier, Cuentecillos tradicionales en la España del Siglo de Oro, Madrid, Gredos, 1975; Folklore y literatura: el cuento oral en el Siglo de Oro, Barcelona, Editorial Crítica, 1978; Cuentos folklóricos españoles del Siglo de Oro, Barcelona, Editorial Crítica, 1983; Tipos cómicos y folklore, Madrid, Edi-6, 1982; «De los cuentos tradicionales a la novela picaresca*, en La Picaresca. Origenes, textos y estructuras. Actas del I Congreso Intemacional sobre la Picaresca, bajo la dirección de Manuel Criado de Val, Madrid, Fundación Universitaria Española, 1979, pp. 335-345; así como los estudios de DANIEL Devoto, Textos y contextos. Estudios sobre la tradición, Madrid, Gredos, 1974; y de Alan C. Soons, Haz y envés del cuento risible en el Siglo de Oro, London, Tamesis Books, 1976; Julio CAMARENA LAUCIRICA, «El cuento de tradición oral y la novela picaresca», Revista de Dialectología y Tradiciones Populares, XLIII, 1988, pp. 67-82; y el volumen conjunto dirigido por J. L. ALONSO HERNÁNDEZ, Literatura y folklore. Problemas de intertextualidad, Salamanca, Ediciones de la Universidad de Salamanca, 1983. Sobre la obra de Cervantes, cabe destacar: MAXIME CHEVALIER, *Literatura oral y ficción cervantina», Prohemio, V, núm. 2-3, sept.dic. 1974, pp. 161-196; MaURICIO MolHo, Cervantes: raices folkloricas, Madrid, Gredos, 1976; AUGUSTIN REDONDO, *Tradición carnavalesca y creación literaria. Del personaje de Sancho Panza al episodio de la Insula Barataria en el Quijoten, Bulletin Hispanique, LXXX, 1978, pp. 39-70; y *El personaje de don Quijote: tradiciones folklorico-literarias, contexto histórico y elaboración cervantinaw, Nueva Revista de Filología Hispanica, XXIX, 1980, pp. 36-59. 
La deuda que los grandes escritores guardan con esta tradición oral ha de ser lógicamente distinta en cada caso: desde el autor que esparce aquí y allá escuetas referencias a anécdotas y cuentecillos perfectamente conocidos por sus lectores, hasta el simple recopilador de materiales folklóricos, o el narrador que ensarta facecias o cuentos con un endeble hilo argumental. De todo hay, y a la crítica literaria, que ha desbrozado ya buena parte del terreno, se le ofrece un campo de investigación de excepcional interés.

El hallazgo de esta fecunda simiente de cultura popular en nuestra literatura clásica, ha llevado, y la reacción era lógica, a negar el proverbial realismo de la creación literaria castellana, y a invalidar de paso cualquier intento de estudiar la literatura de aquella época desde la óptica de la historia social: el campesino zafio y simple, el ciego y su destrón, el estudiante gorrón y trapacista, el hidalgo indigente y vanidoso, el médico matasanos o el alguacil venal, no han llegado a las páginas de la novela, el entremés o la comedia a partir de la observación directa de la realidad de la épo$\mathrm{ca}$, sino que proceden, fundamentalmente, de esa corriente subterránea de literatura oral, ignorada hasta hace poco por la crítica ${ }^{2}$.

Admitir y esclarecer la presencia constante de ese fermento oral en las creaciones cultas del Siglo de Oro, no debe hacernos perder de vista, sin embargo, algunos hechos innegables que desearíamos ilustrar en las páginas que siguen. En primer lugar, el cuentecillo tradicional, la imagen estereotipada de ciertos personajes, el chiste y el refrán, la conseja y la burla, y, aunque en menor medida, también el cuento folklórico, nacen y toman cuerpo sobre un panorama social de contornos precisos, a partir del cual cobran sentido, y cuyos rasgos más sobresalientes reflejan ${ }^{3}$. De otro lado, si admiti-

2 Marcel Bataillon ya habia señalado en sus estudios sobre Lazarillo que cualquier interpretación *ingenuamente realista* de la obra *queda excluida por el hecho de que el autor se vale de una materia folklórica, y que él mismo identifica a su héroe con una figura del folklore español» (Novedad y fecundidad del «Lazarillo de Tormesw, Salamanca, Ediciones Anaya, 1973, p. 27). Para MAXIME CHEVALIER, «la materia novelística que circula por los citados capítulos de Guzmán de Alfarache y del Buscón no es reflejo de una realidad observada directamente, es reflejo de una realidad vista a través del prisma del cuento tradicional (Folklore y literatura, p. 27). El mismo autor ha sef̂alado en otro lugar que, al emplear la palabra realismo para referirnos a Cervantes, nos exponemos a caer en el anacronismo: el punto de partida que nuestro autor eligí para crear ilusión de realidad y vida, no fue el de sla observación metódica de la realidad», sino el de la leyenda oral («Literatura oral y ficción cervantina», pp. 186-187).

3 El problema converso, por ejemplo, sobre cuya importancia en la sociedad de la época tenemos hoy abundantes noticias, dio lugar a una variada tradición oral que ha sido parcialmente recogida por MAXIME CHEVALIER (Cuentecillos tradicionales, pp. 180 y ss.). 
mos, como hace Chevalier ${ }^{4}$, que los tipos y situaciones del folklore tuvieron sus modelos en la vida real, deberemos aceptar también la presencia en las obra de creación de importantes dosis de esa misma realidad directamente observada por el autor, y conceder legitimidad al estudio de ese ámbito histórico, conflictivo y cambiante, en que la literatura del Siglo de Oro se asienta; sin olvidar, además, que la significación de tales temas depende en gran medida del circuito literario y el ámbito ideológico en que se insertan.

Los escritores de aquel periodo no fueron, desde luego, realistas en el sentido estricto: no los imaginamos haciendo acopio de datos, con actitud positivista, en la calle de Toledo o las gradas de San Felipe, ni su obra intentó ser el espejo que transita por el camino de la vida y la refleja con frialdad impasible; aunque tampoco puede ignorarse su capacidad para observar el mundo circundante y para retratarlo con una actitud que, aunque impregnada de idealización, tergiversación o parodia, podemos denominar en un sentido amplio, y sin lugar a dudas anacrónico, realista.

Nos estamos refiriendo, es cierto, a un «realismo de segundo nivel, que constantemente remite a una verdad literaria oral ${ }^{5}$, y que alimenta de cuentos y chistes sus divertidos desfiles de personajillos y peripecias. Pero la tradición oral proporciona únicamente, y no en todos los casos, la materia prima y los arquetipos de la narración, que el autor habrá de adaptar a sus propias finalidades doctrinales, y recubrir con la carne y la savia de lo directamente observado y vivido; y es así como en las obras de aquel periodo se funden, en proporciones diversas, la observación realista, la tradición oral y la intención ideológica explícita o encubierta.

A muchos autores les era difícil desembarazarse del lastre de tópicos que, a propósito de determinados personajes y temas, había acuñado la mentalidad popular; otros, en cambio, supieron aprovechar aquella materia folklórica y tradicional, adaptarla a sus particulares fines, y ensamblarla, sin que se adviertan las suturas, en una obra plena de frescura y originalidad, en que la ficción, aunque nos descubre sus connotaciones doctrinales, se entreteje con un vigoroso retrato de la realidad coetánea que le sirve de trasfondo.

Cervantes es sin duda un ejemplo típico de esta última actitud: a su eficaz destreza en el manejo de cuentecillos y refranes, y a la energía con que los fundamentos de su obra se afirman en el terreno de la cultura popular, se suma el contacto fecundo con la vida circundante, observada y retratada con fidelidad; y a proposito de

- Maxime Chevalier, «De los cuentos tradicionales a la novela picaresca», p. 341 .

5 Ibid., p. 344. 
ello podemos citar, a modo de ejemplo, la génesis literaria de Sancho Panza, personaje que levanta su original figura sobre el suelo del folklore ${ }^{\circ}$, y que encarna además con veracidad escrupulosa al labriego castellano de 1600 , con sus ilusiones, miserias y temores?; o, por mencionar otro caso representativo, recordemos también la habilidad con que nuestro autor actualiza en El retablo de las maravillas un viejo cuento folklórico, y lo aprovecha para mofarse del prurito de limpieza de sangre, tan obsesivamente arraigado entre sus contemporáneos ${ }^{8}$.

Los ejemplos son suficientemente conocidos, y a ellos quisiéramos añadir uno más, que servirá para corroborar nuestras afirmaciones en las páginas que siguen: la concurrencia y la perfecta amalgama de inspiración folklórica y realidad social en el retrato cervantino de las ventas y venteros.

Las ventas y los mesones habían sido utilizados ya como escenario de la ficción literaria durante la Edad Media y el siglo XVI ${ }^{9}$ : en los Cuentos de Canterbury, los peregrinos narran aventuras mientras descansan reunidos en una posada; y en Italia, Franco Sachetti (1330-1400) y Mateo Bandello (1485-1561) utilizaron las ventas para ambientar aventuras amorosas y peripecias de tipo picaresco ${ }^{10}$. Esta tradición italiana fue después trasplantada a España por Mateo Alemán y Cervantes, e imitada por casi toda la novela del siglo XVII. Sin embargo, y como ocurre con otros temas, junto a esta influencia culta discurre paralela y soterrada la tradición autóctona, y de ella toman los novelistas los trazos más gruesos y sobresalientes de los cuadros respectivos "1.

De acuerdo con la imagen prototípica fraguada por la fantasía popular, y cristalizada en cuentecillos y refranes, la venta suele ser

- MAXIME CheVAlier, «Literatura oral y ficción cervantina», pp. 191 y ss,; MAURICIO MOLHo, op. cit., pp. 217 y ss.; y AUgustin REDONDO, «Tradición carnavalesca y creación literaria», pp. 39 y ss.

7 JAVIER SALAZAR RINCÓN, El mundo social del "Quijote», Madrid, Gredos, 1986, capítulo III.

8 MAURICIO MOLHO, op. cit., pp. 37 y ss.; ISAfAS LERNER, «Notas para el Entremés del Retablo de las maravillas: fuente y recreación*, en Estudios de literatura española ofrecidos a Marcos A. Morinigo, Madrid, Insula, 1971, pp. 37-55; y W. ROzEnBLAT, «Cervantes y los conversos. Algunas reflexiones acerca del Retablo de las maravillasn, Anales Cervantinos, XVII, 1978, pp. 99-110.

- Véase EMILIO GONZÁlez LOPEZ, "La evolución del arte cervantino y las ventas de El Quijoten, Revista Hispanica Moderma, XXXIV, 1968, pp. 302-312.

10 Ibid., p. 303.

11 Véase MaXime Chevalier, Tipos cómicos y folklore, pp. 107-112; y especialmente el extenso y documentado estudio de MONIQUE JOLY, La bourle et son interprétation. Recherches sur le passage de la facetie au roman (Espagne, XVIe-XVIIe siècles), Lille, Atelier National de Reprodution des Thèses, Université de Lille, 1982, especialmente pp. 331 y ss. 
un lugar desapacible y mísero, donde el huésped ha de pagar un elevado precio a cambio de las penalidades de un verdadero purgatorio. En dos versiones de un cuento que a propósito de este tema ha recogido Maxime Chevalier ${ }^{12}$, leemos, por ejemplo:

Como el que pedía en una venta de Sierra Morena una sardina, y le
dijeron: - ¿Gollerías buscáis agora? ${ }^{13}$.

Un caminante preguntó en una venta si había cama; respondió la huéspeda: "Sí hay; medí siete pies de ese suelo, y acostaos ahí». Dijo el caminante: "¿Habrá un canto para poner por cabecera?». Respondió la huéspeda: "Más pedí gollerías" ${ }^{14}$.

La misma sensación de penuria y mezquindad se desprende de La sopa de piedras, otro de los cuentos recogidos por Chevalier ${ }^{15}$ :

No auiendo que comer en vna venta, vn passagero se dexó dezir, que él haría vn guisado de piedras; dixo la Ventera, que se holgaría mucho de saber tal curiosidad: pidió él vnas piedras, y lauólas, y luego pidió azeyte para frérlas, diéronsele: luego pidió cebollas, ajos, cominos, especias, y vnos hueuos, con su sal, y pimienta, y hizo vn guisado, que, arrojando las piedras, se le comió ${ }^{16}$.

El ventero suele aparecer además, en las anécdotas y refranes que salpican la conversación, como un cínico y redomado ladrón, con sus puntas de bellaco y cicatero ${ }^{17}$. En el Vocabulario de Correas, por ejemplo, se lee: "A Dios, paredes, ke me voi a ser santo. E iba a ser ventero", y también: "Venteros y gatos, todos son latros" 18; y en su Sobremesa y alivio de caminantes, Joan de Timoneda recoge este cuentecillo, que debió de ser tradicional, y que también Melchor de Santa Cruz incluyó en su repertorio ${ }^{19}$ :

Un caballero vino a posar en uno de dos mesones que estaban a los lados de una cruz de piedra, y pidió para su cuartago medio celemín de cebada, y, vuelto a reconocerle, halló que le habían quitado della. Salió a la puerta, y dijo razonando con la cruz:

\footnotetext{
12 Cuentecillos tradicionales, p. 245.

13 JUAN DE MAL. LARA, Filosofía vulgar [1568], Barcelona, Selecciones Bibliofilas, 1958-1959, 3 vols., vol. I, p. 396.

14 Melchor De SANTA CRUz, Floresta Española [1574], edic, de Maximiliano Cabañas, Madrid, Cátedra, Letras Hispánicas, 1996, p. 501, núm. 855.

15 Maxime Chevalier, Cuentos folklóricos, p. 296.

16. PEDRO GONZALEZ DE GODOY, Discursos serio-jocosos sobre el agua de la vida [1682], Madrid, Sociedad de Bibliófilos Españoles, 1959, p. 116.

17 Para la imagen tradicional del ventero y su significación, véase MoNIQUe Joly, op. cit., pp. 371 y ss.

is GoNZALO CORREAS, Vocabulario de refranes y frases proverbiales [1627], edición de Louis Combet, Bourdeaux, Institut d'Etudes Iberiques et Ibéro-Américaines de l'Université de Bourdeaux, 1967, pp. 13 y 518.

19 Melchor de SANTA Cruz, op. cit., p. 271, núm. 304.
} 
- ¡Oh, Señor!, ¿y hasta aqui os habéis puesto entre dos ladrones?

Respondió el mesonero del otro mesón, que estaba a la puerta:

-Señor, ¿y qué merezco yo?

Dijo el caballero:

- Sed vos el que se salvó y callad ${ }^{20}$.

Este tópico del ventero ladrón, presente también en la novela italiana ${ }^{21}$, se repite hasta la saciedad en la literatura castellana del siglo XVII. Guzmán de Alfarache, por ejemplo, se hospedó al salir de Sevilla en el «mesón del mayor ladrón que se hallaba en la comarca» ${ }^{22}$; en la segunda parte de la novela comenta: "Salí de ladrón y di en ventero" ${ }^{23}$; en otra ocasión censura a "venteros y mesoneros, que por mal servicio llevan buena paga, robando públicamente" ${ }^{24}$; $y$ añade:

La palabra del ventero es una sentencia definitiva: no hay a quien suplicar, sino a la bolsa. Y no aprovechan bravatas, que son los más cuadrilleros y por su mal antojo siguen a un hombre callando hasta poblado y alli le probarán que quiso poner fuego a la venta y le dio de palos o le forzó la mujer o hija, sólo por hacer mal y vengarse.

¡Qué de robos, qué de tiranías, cuántas desvergüenzas, qué de maldades pasan en ventas y posadas! ¡Qué poco se teme a Dios ni a sus ministros y justicias! ${ }^{25}$.

Don Gregorio Guadaña se hosped6 en «una venta que saltea en Sierra Morena», saliéndole "a recibir o a robar, que todo es uno, el ventero, descendiendo por línea recta del mal ladrón" ${ }^{26}$. En el alivio VII de El Pasajero, tras narrar la historia de un ventero que roba públicamente con título de cuadrillero de la Santa Hermandad, igual que en el Guzmán ${ }^{27}$, uno de los interlocutores comenta:

¿Hállase por ventura algún ventero canonizado? Como habitadores del campo, son todos aves de rapiña y fieras de crecidas garras. ¿Qué cuidado puede ser bastante para enfrenar sus robos y demasías? Es forzo-

20 JOAN DE TIMONEDA, JOAN ARAgonés, Buen aviso y portacuentos. El sobremesa y alivio de caminantes. Cuentos, edic. de Pilar Cuartero y Maxime Chevalier, Madrid, Espasa Calpe, Clásicos Castellanos nueva serie, 1990, pp. 236-237, núm. 55.

21 ENRIQUe GONZÁleZ LÓPEZ, art. cit., p. 304.

22 MATEO AlemÁN, Guzmán de Alfarache, en La novela picaresca española, edición de Ángel Valbuena Prat, Madrid, Aguilar, 1986, 2 vols., vol. I, p. 325.

23 Ibid., p. 562.

24 Ibfd., p. 370.

25 Ibid.

26. Antonio Enrtouez Gomez, Vida de don Gregorio Guadaña, ibid., vol. II, p. 769 .

${ }_{27}$ El motivo del ventero-cuadrillero, además de corresponder a una realidad histórica atestiguable por otras fuentes, se convirtió en otro de los tópicos de la literatura de la época, estudiado también por MONIQUE JOLY (op. cit., pp. 375 y ss.). 
so permitirlos en tales desiertos, donde sin su socorro peligrarían las vidas de muchos caminantes, que fuera peor que las bolsas ${ }^{28}$.

En la Historia de la vida del Buscón, Pablos y don Diego se hospedaron camino de Alcalá en una venta en la que: «El ventero era morisco y ladrón, que en mi vida vi perro y gato juntos con la paz que aquel día” ${ }^{29}$. En una de las letrillas del mismo autor, leemos:

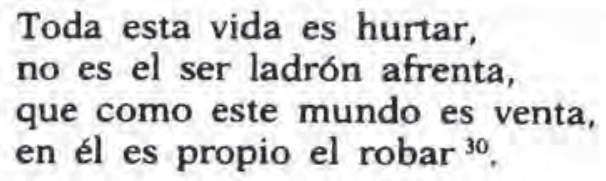

En la Premática del tiempo, también de Quevedo:

...informado de los grandes robos y latrocinios que de ordinario se hacen en ventas, mandamos que nadie sea atrevido de aquí adelante a llamarlas ventas, sino hurtos, pues en ellas hurtan más que venden ${ }^{31}$.

$\mathrm{Y}$ en el Entremés de la venta, del mismo autor, la moza canta:

Ventero murió mi padre;

Satanás se lo llevó,

porque no piense el Infierno

que hubo sólo un mal ladrón ${ }^{32}$.

López de Ubeda llamó al mesón "purgatorio de bolsas», «espuela de caminantes", y "desquiladero apacible" ${ }^{33}$; $y$ en una poesía de don Gabriel de León Marchante leemos:

La comida de la venta, como siempre puerca y cara, porque el ventero era Caco y la ventera era caca ${ }^{34}$.

$\mathrm{Y}$ en efecto, junto a los robos proverbiales que en la venta se cometen, otro lugar común en la literatura del periodo es el que

28 CRISTÓbal SuArez de Figueroa, El Pasajero. Advertencias utilísimas a la vida humana [1617], edición de Francisco Rodriguez Marín, Madrid, Biblioteca Renacimiento, 1913, pp. 260-261.

29 FRANCISCO DE QUEVEdo, Historia de la vida del Buscón, en Obras completas, estudio preliminar, edición y notas de Felicidad Buendía, Madrid, Aguilar, 6. edic., 1974, 2 vols., vol. I, p. 331.

${ }^{30}$ Ibfd., vol. II, p. 205.

31 Ibid., vol. I, p. 113.

32 Ibid., vol. II, p. 538.

33 FRANCISCO LOPEZ DE ÚBEDA, La picara Justina, en La novela picaresca española, edic. cit., vol. I, p. 919.

${ }^{34}$ Citado por Francisco Rodriguez Martn, en su edición de El Quijote, Madrid, Ediciones Atlas, 1947-1949, 10 vols., vol. I, p. 118. 
evoca a la mujer del ventero, desaseada y fea, y nos recuerda la suciedad de las comidas y el mal servicio que en tales sitios suele ofrecerse a los huéspedes ${ }^{35}$. Ya en 1577, Villalba y Estaña escribe:
A la venta del Negro hemos llegado, y negro el pan, y negros los manteles, el caldo negro y el cabrón chamuscado y negros de la güespeda aranbeles ${ }^{36}$.

Guzmán, en la primera venta que conoció al iniciar sus andanzas, hubo de engullir un emplastro de huevos empollados, servidos con «un barredero de horno", "un salero hecho de un suelo de cántaro", "un tiesto de gallina lleno de agua", y «media hogaza más negra que los manteles" ${ }^{37}$, guisado todo ello con "aceite negro", en una "sartén puerca», y por una "ventera legañosa" ${ }^{38}$. Lázaro visitó una venta, a una legua de Valladolid, y al ir a comer se encontró con que «El pan era tan negro como los manteles, que parecían túnica de penitente o barredero de horno ${ }^{39}$. El donado hablador Alonso, tras largas caminatas, «ordinariamente llegaba a la posada con un cansancio mortal, $y$ con tan poco refrigerio, que aun agua dulce no se hallaba" ${ }^{40}$. En una venta de Sierra Morena que visitó Gregorio Guadaña:

El ventero puso una mesa triangular, y en ella unos manteles de Etiopía. El poeta no pudo creer sino que habían desollado algún negro, y nos le vendían por tela. En medio de la mesa puso por salero un pedazo de medellín, salado a las mil maravillas. Un jifero, que podía desjarretar un toro, ocupaba la mejor parte de la mesa, y a su lado tres platos, tan faltos como quebrados ${ }^{41}$.

Y en la venta que pintó Quevedo en su entremés, la moza ofrece a los comensales:

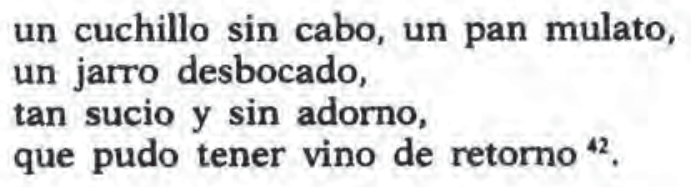

35 MONIQUe JOLY, op. cit., p. 394 y ss.

36 BaRtholomé DE Villalba y Estaña, El Pelegrino curioso, y grandezas de España [1577], edic. de Pascual de Gayangos, Madrid, Sociedad de Bibliófilos Españoles, 1886-1889, 2 vols., vol. II, p. 24.

37 Mateo AlemÁ, Guzmán de Alfarache, en La novela picaresca española, edic. cit., vol. I, p. 316.

38 Ibid., p. 318.

39 H. DE LUNA, Segunda parte de Lazarillo de Tormes, ibid., vol. I, p. 161.

40 JERÓNIMO DE ALCALÁ YANEZ Y RIVERA, El donado hablador Alonso, mozo de muchos amos, ibtd., vol, II, p. 205,

4t Antonio EnRfouez Gomez, Vida de don Gregorio Guadaña, ibid., vol. II, p. 770.

42 Francisco de Quevedo, El entremés de la venta, en Obras completas, edic. cit., vol. II, p. 539. 
La mala fama de los hospedajes generó, hasta hacerla proverbial e incorporarla al folklore, la imagen del ventero embaidor, que obra a diario la milagrosa trasmutación de los comestibles más dispares ${ }^{43}$; y ya en 1573, Eugenio Salazar comenta en una de sus cartas, a propósito de este tema:

Si vn día coméys en vna venta, donde el ventero, cariacuchillado, experto en la seguida y exerçitado en lo de rapapelo, y agora quadrillero de la Santa Hermandad, os vende el gato por liebre, el macho por carnero, la çeçina de roçín por de vaca, y el vinagre aguado por vino puro ${ }^{44}$.

\section{Covarrubias glosaba así el conocido refrán:}

Vender el gato por liebre, engañar en la mercadería; tomado de los venteros, de los quales se sospecha que lo hazen a necessidad y echan un asno en adobo y lo venden por ternera. Deve ser gracia y para encarecer quán tiranos y de poca conciencia son algunos ${ }^{45}$.

El ventero que acaba de dar a Guzmán muleto por ternera, asegura hipócritamente ante sus huéspedes:

¡Loada sea la limpieza de la Virgen María, que con toda mi pobreza no hay en mi casa mal trato! Cada cosa se vende por lo que es; no gato por conejo, ni oveja por carnero ${ }^{46}$.

El padre de la pícara Justina, avezado en tales artes, recomienda a sus hijas:

Si viene a vuestra casa un gato muerto, honradle, y decid que es liebre; al gallo llamadle capón; al grajo, palomino; a la carpa, lancurdia; a la lancurdia, trucha; al pato, pavo. Las frutas no digáis que son vecinas de Mansilla, que es decir que son villanas y montañesas, sino que vinieron de Bretaña con los godos. Que es villanía no honrar, pues la honra torna siempre a su oriente ${ }^{4}$.

Francisco de Santos recuerda a un personaje perseguido por la justicia, el cual:

...por huir de estos azotes se ha hecho figonero, y a vender gato por conejo, cuervo por palomo, cordero por cabrito, macho por carnero, ga-

43 MONIQUe Joly, op. cit., pp. 488 y ss.

44 Eugenio De Salazar, Cartas, Madrid, Bibliofilos Españoles, 1966, p. 74.

45. SEBAStian DE CovarRUBias, Tesoro de la Lengua Castellana o Española [1611], Madrid, Turner, 1979, p. 632. Sobre las manifestaciones literarias de este tema, véase también José CARLOS CAPEL, Pícaros, ollas, inquisidores y frailes, Barcelona, Argos Vergara, 1985, pp. 95 y ss.

46 MATEO ALEMAN, Guzmán de Alfarache, en La novela picaresca española, edic. cit., vol. I, p. 329.

47 Francisco LOPEZ DE Úbeda, La picara Justina, ibid., vol. I, p. 923. 
llos por capones y gallinas cluecas por pollas tiernas, ha engordado de bolsa y carnes tan demasiadamente que al médico le parece que se le pierde el alma ${ }^{48}$.

En El alguacil endemoniado, llegó al infierno un mohatrero que "se condenaba por haber vendido gato por liebre, y pusímoslo de pies con los venteros, que dan lo mismon ${ }^{49}$; y en las ollas que aparecen en el Entremés de la venta, hasta "las lechuzas / pasan por pollasn ${ }^{50}$.

Un motivo similar al que hemos comentado aparece en los cuentecillos reunidos por Maxime Chevalier ${ }^{51}$ :

Preguntando un caminante a un ventero de Sierra Morena qué tenfa de comer, respondió que no había otra cosa sino huevos. Replicó el caminante: « ¿Habrá alguna carne salpresa, como la que nos distes hoy ha ocho días, cuando pasé por aquí?, Que, en verdad no he comido en mi vida cosa que mejor me supiesex. Dijo un mochacho, hijo del ventero: "Caro costarfa si cada semana se nos hubiese de morir un rocín ${ }^{52}$.

Y en el Entremés de la venta, asistimos a un diálogo semejante entre un estudiante y la moza:

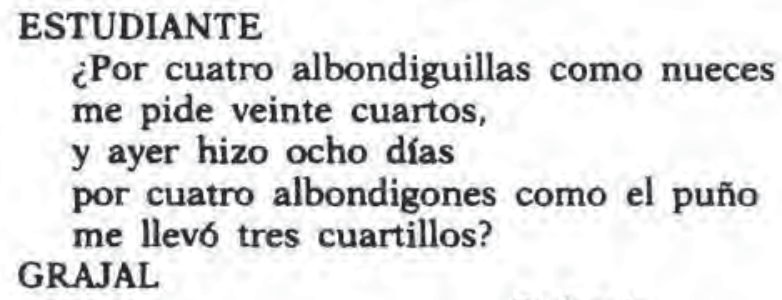

Sí harfa, mas no se muere un asno cada día ${ }^{53}$.

Junto a las frecuentes alusiones a la incomodidad de los alojamientos y la mala calaña de los venteros, numerosos testimonios nos hablan de la pervivencia, durante el Siglo de Oro, de una promiscuidad sexual opuesta a la moral oficial, que tuvo en ventas y mesones un cobijo constante y seguro, a juzgar por algunos testimonios, y que también pasó a formar parte de la tradición literaria oral y escrita que venimos comentando ${ }^{54}$ : "Figa verdal i moza de ostal, palpándose madura", dice un refrán recogido por Correas ${ }^{55}$;

48 Francisco SANTos, El no importa de España y la verdad en el potro [1667], edic. de Julio Rodríguez Puértolas, London, Tamesis Books, 1973, p. 86.

49 FRANCISCO DE QUEVEDO, Obras completas, edic. cit., vol. I, p. 151.

so Ibid., vol. II, p. 537.

51 Cuentecillos tradicionales, p. 246.

52 MELCHOR DE SANTA CRUz, op. cit., pp. 569-570, núm. 1023.

53 FrANCISCO DE QUEVEDO, Obras completas, edic. cit., vol. II, p. 540 ,

54 MONIOUE JOLY, op. cit., pp. 409 y ss.

55 Gonzalo Correas, op. cit., p. 340. 
otro del mismo repertorio reza: «Ni moça de mesonero, ni kostal de karvonero. Sin aguxero" ${ }^{56}$. De acuerdo con esa tradición, que convertía a las ventas y mesones en lugares de prostitución encubierta, el padre de la pícara Justina recomendaba a sus hijas:

...que nunca falte una de vosotras a la puerta bien compuesta y arreada, que una moza a la puerta del mesón sirve de tablilla y altabaque, en especial si es de noche y junto a la candela ${ }^{57}$.

$\mathrm{Y}$ al evocar la historia de su madre, Teresa de Manzanares recuerda:

Ya tenemos a mi señora madre (buen siglo haya) acomodada en un mesón de los de más nombre que había en la Cava de San Francisco, cobrando desde su llegada el nombre del "Mesón de las dos hermosas", por ella y la otra moza que halló en él.

Era buena mujer la huéspeda, y viendo que el lucimiento de su criada le era mejoría de su casa y crédito de su mesón, se holgó que sin pedirla nada adelantado tuviese con qué vestirse, y así se ofreció a salir a comprar con ella lo necesario ${ }^{58}$.

Como acertadamente ha señalado Maxime Chevalier ${ }^{59}$, cuando un autor elige determinados personajes, la materia folklórica invade su imaginación, y orienta el contenido, la intención y hasta los detalles de su obra, tal como lo demuestran los ejemplos anteriores: basta que la venta y el ventero se asomen a las páginas de un libro, para que surja la inevitable retahíla de incomodidades, trapacerías y guisos repugnantes, tomados todos ellos de esa literatura oral presente por doquier en el vivir cotidiano de la época.

Sobre este armazón básico de temas folklóricos, cada autor construye la trama de su novela añadiendo más o menos ingredientes, y aunque es difícil saber dónde termina la paráfrasis amplificada del cuentecillo y dónde empieza el trasvase de una realidad directamente observada, parece evidente, como ya hemos indicado, la existencia en la literatura de la época de una sólida fusión de tradición oral y observación realista. Y ello se comprueba fácilmente al repasar la obra de Cervantes: nuestro autor conoce los relatos orales sobre el tema de las ventas, y los utiliza como punto de partida en sus retratos de caminos y hospedajes; pero los detalles numerosos y precisos que salpican sus obras, proceden sin duda de

\footnotetext{
56 Ibid., p. 238.
}

57 FRANCISCO LOPEZ DE ÚBEDA, La picara Justina, en La novela picaresca española, edic. cit., vol. I, p. 924.

58 Alonso DE CAstillo Solórzano, la niña de los embustes, Teresa de Manzanares, ibid., vol. II, p. 329.

59. Folklore y literatura, pp. 143-144. 
experiencias vividas en sus viajes por tierras de Castilla y Andalucía, y son el fruto de su capacidad de observación y de un exacto conocimiento de la tradición folklórica ${ }^{60}$.

Para comprobar la existencia de esta doble vertiente estética en la novela cervantina, acudiremos a un conjunto de documentos especialmente útiles para estudiar el tema que aquí nos planteamos: el testimonio de los viajeros extranjeros que visitaron España en la época de los Austrias, y nos dejaron un recuerdo escrito de sus impresiones ${ }^{61}$. Aquellos personajes, aunque llegasen a la Península con prejuicios consabidos, y sus testimonios no sean fiables por completo ${ }^{62}$, no estaban siempre familiarizados con nuestra tradición folklórica, ni con los tópicos de la venta incómoda y el ventero ladrón: las coincidencias, bastante curiosas y frecuentes, entre estas crónicas y los relatos cervantinos, y de ambas con el folklore, sólo pueden proceder de experiencias vividas en condiciones análogas por sus autores.

En numerosas relaciones de viajes y embajadas, la incomodidad de las ventas españolas es tema común, que se achaca generalmente a la pobreza del suelo. El alemán J. W. Neumair von Ramssla, que viajó por España hacia 1600, explica, por ejemplo:

En las carreteras se topa a veces con una casucha de miserable aspecto, provista de una mesa no mal acondicionada, pero en la cual no hay nada de qué echar mano. Si alguno toma asiento, aunque solo sea para aliviarse un poco de las fatigas del camino, tiene que pagar solamente por eso al hospedero, aunque no haya encargado nada de comer o beber, seis maravedís por la posada, y sin recibir una palabra de cortesía ni deferencia ${ }^{63}$.

William Lithgow, que viajó por España hacia 1620 sufriendo muchas incomodidades, observa:

60 Recuérdese, a propósito de la presencia del tema en la obra de Cervantes, el libro de RICARDO DEL ARCO Y GARAY, La sociedad española en las obras de Cervantes, Madrid, Patronato del IV Centenario del Nacimiento de Cervantes, 1951, pp. 600 y ss.

61 Sobre las características de los hospedajes en la época de los Austrias y su reflejo en las crónicas de los viajeros, véase MOISÉs GARCIA DE LA TORRE, "Las ventas en la España del Antiguo Régimen», Hispania, XXXIX, 1979, pp. 397-453; y Julio Caro Baroja, "Las ventas durante el Siglo de Oro", en Jardín de flores raras, Barcelona, Circulo de lectores, 1993, pp. 147-154.

62 En efecto, como ha señalado MONIQUE Joly (op. cit., p. 356), muchos de estos viajeros conocían el tópico de las ventas españolas y su denostada calidad, a través de las crónicas y relaciones de quienes les precedieron, y también a partir de la imagen de España que nuestros novelistas difundieron por Europa, especialmente desde 1600. Para una discusión de este problema, véase también MoISÉS GARCIA DE LA TORRE, "Realidad histórica y ficción cervantina: El mundo de los caminos en Cervantes y su época», Anales Cervantinos, XX, 1982, pp. 113-123.

63 Citado en JAIMe Vicens Vives, Historia social y económica de España y América, Barcelona, Editorial Vicens Vives, 1972, 5 vols., vol. III, p. 185. 
...el hospedaje es malo y pobre, hay gran escasez de camas y son caras, y no se encuentra ninguna comida preparada, a menos que se la compre uno cruda y la mande guisar, o se la guise uno mismo ${ }^{64}$.

Un folleto inglés, titulado Vox Populi, publicado en 1624, explica que el Príncipe Carlos y sus acompañantes habían vuelto de España diciendo:

...que en su vida habían visitado un país tan pobre, donde no podían conseguir comida, ni para ellos ni para sus caballos, y donde no habían visto un puñado de hierba en 200 millas a caballo, y que si comían en un sítio se veían obligados a seguir 30640 millas más antes de encontrar algo para su cena; $y$, luego, tal vez un pedazo de cabrito duro, o callos ${ }^{65}$.

$\mathrm{Al}$ atravesar Sierra Morena en 1680, Thomas Williams comenta:

Comíamos donde encontrábamos una fuente y dormíamos en sitios llamados ventas, o sea, un sitio que tiene techo y paredes de tierra y piedra, y donde se ponen las mulas a un lado y uno mismo al otro. No hay siquiera un taburete en qué sentarse, y el suelo no está más llano que el camino real ${ }^{\text {b6. }}$.

Unos años después, hacia 1693 , la situación no había mejorado mucho, según explica William Bromley, ya que:

La gran pobreza de este país, y, por consiguiente, el mal hospedaje que se encuentra en camino, hace muy incómodo el viajar por el ${ }^{67}$.

Todavía en 1777, el barón de Bourgoing se lamentaba:

Pero a lo que no se acostumbra uno con facilidad es a las posadas españolas, que, por lo general, son detestables. Alojamiento, lecho, servicio: todo es malo. Para obtener la comida más frugal tiene uno que procurarse por sí mismo la carne, el pan y demás comestibles ${ }^{68}$.

\section{Y en 1845, Richard Ford apunta:}

...las posadas en general son malas y con frecuencia muy malas, e incluso cuando son las mejores de que dispone el pais resultan insignificantes si las comparamos con aquellas a que el inglés está acostumbrado en su tierra ${ }^{69}$.

${ }^{\circ}$ PATRICIA ShAW FAIRMAN, España vista por los ingleses del siglo XVII, Madrid, SGEL, 1981, p. 71.

65 Ibid., p. 75

66 Ibid., p. 79.

67 Ibid., p. 80.

68 José Garcia Mercadal, Viajes de extranjeros por España y Portugal, Madrid, Aguilar, 1952-1962, 3 vols., vol. III, p. 934. Pueden verse más datos sobre los caminos y los hospedajes españoles en el siglo XVIII, en ANA CLARA GUERRERo, Viajeros británicos en la España del siglo XVIII, Madrid, Aguilar, 1990, pp. 91-108.

69 RICHARD FORD, Manual para viajeros por España y lectores en casa. Observaciones generales, Madrid, Turner, 1982, p. 59. 
Un lugar común en casi todos estos relatos es la imposibilidad de hallar en las ventas un lugar decente y cómodo en que dormir: generalmente el viajero ha de acostarse en el suelo, en una tabla, o pasar la noche sentado junto al fuego. William Edgeman, por ejemplo, que acompañó por España a Sir Francis Cottington y Edward Hyde en 1649, en un viaje de tipo diplomático, se detuvo en una venta de Hinojosa del Campo (Soria):

...donde no había más que una sola cama para Su Excelencia, mientras los demás tuvimos que pasar aquella noche junto al fuego en la cocina ${ }^{70}$.

En estos lugares, según observó Mme. d'Aulnoy hacia 1680:

...la cuadra está llena de mulas y de arrieros, que se hacen las camas con las albardas de sus mulas durante la noche, y durante el día les sirven de mesas ${ }^{71}$.

Aunque las condiciones en que se hospedan los demás viajeros no son mucho mejores: "muy a menudo hay que dormir en el suelo [explicaba A. Jouvin en 1672], si no se sirve uno de su capa como colchón" 72; y Sir Richard Wynn, yendo hacia Madrid en 1623, se había detenido en un lugar "donde no había más que una cuadra y nos vimos obligados a tumbarnos toda la noche sobre las tablas del graneron ${ }^{73}$.

Cuando la venta dispone de habitaciones, éstas no suelen ser mucho más confortables: Robert Bargrave disfrutó en Villagordo (Cuenca), el año 1654, de "una piojosa cama de hierba en un tugurio asqueroso" ${ }^{74}$. En el viaje que emprendió el año 1666, Jean Muret no encontró "más que jergones, sábanas llenas de miseria y puercas y malolientes habitaciones» ${ }^{75}$. Y Sir Richard Wynn se alojó en:

...una habitación alargada, en tal mal estado que temíamos a cada momento que se hundiese encima de nosotros. No había ventanas con cristales (porque aún no se conocían en aquellas regiones), pero no careciamos de aire. Pues no había ni un palmo de aquel Aposento Real que no estuviese lleno de agujeros, con los cuales tuvimos trato pocas horas después, pues hacía una noche de un frío muy cortante ${ }^{76}$.

70 Ibid., p. 76.

71 José Garcia Mercadal, op, cit., vol, II, p. 951.

72 Ibid., p. 751.

73 Patricia Shaw Fairman, op. cit., p. 73.

74 Ibid., p. 78.

75 José Garcta MERCADAl, op. cit., vol. II, p. 713.

76 Patricia Shaw Fairman, op, cit., p. 72. También el Mayor Whiteford Dalrymple se alojo en 1774 en una posada «que tenfa en uno de sus extremos una cocina y una cuadra en el otro. Entre esas dos habitaciones no había más que un 
Tampoco nos ofrecen los documentos de la época un retrato favorable de cocinas, comidas y cocineros:

No creo que se pueda representar mejor el infierno [escribe Mme. d'Aulnoy] que imaginándose esa clase de cocinas y las gentes que dentro de ellas se encuentran; porque sin contar ese humo horrible, que ciega y sofoca, son una docena de hombres y otras tantas mujeres más negros que diablos, malolientes y sucios como cerdos y vestidos como unos pordioseros ${ }^{77}$.

Y en la relación del viaje que efectuó Antoine de Brunel en 1655, se lee:

La cocina es un sitio donde se enciende el fuego en el medio, bajo una gran campana o chimenea, que despide humo con tal espesor, que a menudo se cree estar en alguna guarida de zorra, de la que se quiere hacer salir al animal que alli se refugia. Una mujer o un hombre, que se parecen a unos pobres piojosos y cubiertos de andrajos, os miden el vino que sacan de un pellejo de cabrón o de puerco ${ }^{78}$.

Si por casualidad se halla algo de comida en estos lugares, suele ser, según explica Robert Bargrave, «del mismo tenor que el hospedaje, la peor que se podría imaginar para un viajero hambriento" ${ }^{79}$. Y así lo sufrió también Sir Richard Wynn al salir de Santander y llegar a la posada, donde «habían colocado una tabla en lugar de mesa", en la cual "No había ni mantel ni servilletas", y en la que tuvieron para comer unos huevos, con medio cabrito colgado encima del fuego hasta que se había quemadon ${ }^{80}$.

Naturalmente no hay regla sin excepción, y en los relatos de los viajeros, entre quejas e improperios, encontramos el recuerdo de la cama limpia, el ventero amable y la comida bien aderezada. Sir Richard Wynn, por ejemplo, comenta que en la fonda de Escalada, al norte de Burgos, «nos trataron muy bien, pues cenamos un pavo gordo, y tuvimos camas muy buenas" ${ }^{81}$. Y Thomas Williams sacó una impresión parecida durante su estancia en una posada de Sevilla que:

pequeño espacio para poner los equipajes y para descansar los viajeros rendidos [...]. Nos vimos obligados a poner paja en el suelo para servirnos de camas, y nuestros capotes como mantas, porque de camas no había que hablar» (José GaRcfa MERCADAL, op. cit., vol. III, p. 647). Y todavía Richard Ford visito lugares en que los animales reciben un trato excelente, mientras que el viajero atiene que salir en busca de lo que necesita y sólo se le adjudica una pequeña parte del pajar, $\mathrm{y}$ aun así tiene que alojarse entre las bestias, abajo, o entre los cajones y sacos de forraje del desván, arriba» (RICHARD FORD, op. cit., p. 65).

77 Jose Garcfa MERCADAL, op. cit., vol. II, p. 952.

78 Ibid., pp. 405-406.

79 PATRicia ShaW FaIRMAN, op. cit., p. 78.

so Ibid., p. 71.

81 Patricia Shaw Fairman, op. cit., p. 73. 
...estaba construida alrededor de una patio bien pavimentado y refrescado con plantas todo alrededor, y las habitaciones de la planta baja estaban muy bien arregladas, las camas y la ropa, finas y limpias. Esta posada tenía un cocinero excelente, y hacía falta ser muy quisquilloso para que no le gustara a uno la comida ${ }^{82}$.

También el tópico del ventero ladrón, tan difundido en la tradición oral, reflejaba así mismo, aunque exagerándola, una realidad que podemos comprobar por otros testimonios coetáneos. Los venteros, según Mme. d'Aulnoy:

Todos ellos son más ladrones que las urracas, y tan sólo se apresuran a serviros para quitaros algo, sea lo que sea, aunque sólo se trate de un alfiler ${ }^{83}$.

En un arbitrio proyectado a fines del siglo XVI, para mejorar el servicio de mesones y ventas, y contribuir al saneamiento de la Hacienda Real, se alude a:

...la maldad y tiranía que se usa en las ventas en las quales, como saben que forçosamente an de gastar la prouisión que tienen, venden vna tajada de baca muy dura por dos Reales, el pan por vn ojo de la cara y el vino que mejor diré vinagre a ochenta y a ciento todo lo qual es vn público latrocinio ${ }^{84}$.

Y Lope de Deza explica que los hosteleros:

...buscan los páramos más desiertos, donde edificar sus ventas para hospedar alli, y dar de comer a los que por largos, y trabajosos caminos, acuden maltratados de las tempestades, o de los calores: y después de auer hecho esta obra tan piadosa, no los dexan yr como amigos, ni les hazen, ni aun vna pequeña gracia, antes los fuerçan como a enemigos o prisioneros a que se rediman, y rescaten despojándolos de quanto traen ${ }^{85}$.

Y en cuanto a la facilidad con que las mozas ofrecen sus encantos a los viajeros, tema común en la tradición folklórica, como ya vimos, bastará recordar un suceso que refiere François Bertaut, ocurrido durante su viaje a España en 1659:

...las muchachas del alojamiento donde dormimos, porque no dormimos donde habiamos cenado, atacaron a mi criado, que estaba muy molesto porque no podía entender lo que le decían, ni hacerse entender él mismo, y le preguntaron cuál de las tres que allí estaban quería que fuese a dormir con él. Como no respondió nada o respondió mal, y dijo

\footnotetext{
82 Ibtd., p. 78.

B3 José Garcia MERCadal, op. cit., vol. II, p. 952.

84 VALERIO FORT, Arbitrio sobre mesones, en MOISÉs GARCIA DE LA TORRE, art. cit., p. 449.

85 LOPE DE DEZA, Gouiemo polytico de la agricultura, Madrid, 1618, fol. 9.
} 
que él no quería ninguna, ellas le pusieron en su cama una muñeca de madera, a la que vistieron agradablemente, y eso nos divirtió ${ }^{86}$.

Las descripciones cervantinas de ventas y posadas, además de evocar aquí y allá detalles de la tradición oral, coinciden en lo sustancial con el testimonio de estos viajeros. En La fuerza de la sangre, por ejemplo, nuestro autor señala que los soldados españoles conservan un buen recuerdo de los hospedajes de Italia, especialmente:

...cuando de aquellas partes vienen a estas y pasan por la estrecheza e incomodidades de las ventas y mesones de España ${ }^{87}$.

En la novela de Las dos doncellas, Teodosia pasó la noche en una posada de Castilblanco, y de madrugada se quedó sentada en su habitación:

...esperando el día, que de allí a poco espacio dio señal de su venida con la luz que entraba por los muchos lugares y entradas que tienen los aposentos de los mesones y ventas ${ }^{88}$.

También Don Quijote se hospeda en lugares muy parecidos a los que describen los viajeros. En la venta donde el hidalgo va a ser armado caballero, por ejemplo, el ventero le advierte:

Si vuestra merced, señor caballero, busca posada, amén del lecho (porque en esta venta no hay ninguno), todo lo demás se hallará en ella en mucha abundancia ${ }^{89}$.

Los arrieros, según comenta el Licenciado Vidriera, son gente acostumbrada a tales hospedajes, pues han hecho «divorcio con las sábanas y se han casado con las enjalmas» ${ }^{90}$. A nuestro caballero, en cambio, cuando llegó a la venta de Juan Palomeque, le hicieron una mala cama:

...en un camaranchón que, en otros tiempos, daba manifiestos indicios que había servido de pajar muchos años; en el cual también alojaba un harriero, que tenía su cama hecha un poco más allá de la de nuestro don Quijote. $\mathrm{Y}$ aunque era de las enjalmas y mantas de sus machos, hacía mucha ventaja a la de don Quijote, que sólo contenía cuatro mal lisas tablas sobre dos no muy iguales bancos, y un colchón

86 José Garcta MERCadal, op. cit., vol. II, p. 55.

87 Miguel De Cervantes SAAVEDRA, Novelas ejemplares, en Obras Completas, edición de Ángel Valbuena Prat, Madrid, Aguilar, 1986, 2 vols., vol. II, p. 148. Para todas las citas de la obra de Cervantes utilizamos esta edición, a la que nos referiremos con las siglas $O C$, indicando a continuación el volumen y la página.

88 Novelas ejemplares, $O C$, II, 214.

89 Don Quijote (I, 2), OC, II, 313.

so Novelas ejemplares, $O C$, II, 136. 
que en lo sutil parecía colcha, lleno de bodoques, que, a no mostrar que eran de lana por algunas roturas, al tiento, en la dureza, semejaban de guijarro, y dos sábanas hechas de cuero de adarga, y una frazada cuyos hilos, si se quisieran contar, no se perdiera uno solo de la cuenta ${ }^{9 t}$.

$\mathrm{Y}$ entre el lecho de don Quijote y el del arriero, «en mitad de aquel estrellado establon, también «hizo el suyo Sancho, que sólo contenfa una estera de enea y una manta, que antes mostraba ser de anjeo tundido que de lana" ${ }^{92}$.

Cuando el Oidor llegó a esta misma venta, la huéspeda advirtió a uno de sus acompañantes que en aquel establecimiento no había camas, aunque:

...si es que su merced del señor Oidor la trae, que sí debe de traer, entre en buen hora, que yo y mi marido nos saldremos de nuestro aposento por acomodar a su merced ${ }^{93}$.

Con lo cual, los hombres que se alojaban en la venta tuvieron que pasar aquella noche en vela, mientras que Dorotea, Clara, Luscinda y Zoraida:

...con parte de la estrecha cama del Ventero y con la mitad de la que el Oidor trafa, se acomodaron aquella noche mejor de lo que pensaban ${ }^{94}$.

Si las camas son escasa y sucias, o simplemente no existen en la mayoría de las ventas, los mantenimientos no son mucho mejores: Carriazo y Avendaño, los protagonistas de La ilustre fregona, al llegar a la Posada del Sevillano:

Pidieron de cenar; respondióles Argüello que en aquella posada no daban de comer a nadie, puesto que guisaban y aderezaban lo que los huéspedes traĺan de fuera comprado; pero que bodegones y casas de estado había cerca donde, sin escrúpulo de conciencia, podían ir a cenar lo que quisiesen ${ }^{95}$.

La respuesta de la moza no es invención novelesca: aunque $\mathrm{Fe}$ lipe II había ordenado en 1560, igual que sus antecesores, que en los mesones upuedan tener y vender, para la provisión y mantenimiento de los caminantes, las cosas de comer y beber, así para sus personas como para sus bestias" ${ }^{96}$, una vieja costumbre, hecha ley

\footnotetext{
91 Don Quijote (I, 16), OC, II, 362.

92 Ibtd. (I, 16), OC, II, 363.

93 Ibid. (I, 42), OC, II, 523.

94 Ibid. (I, 42), OC, II, 524.

9s Novelas ejemplares, OC, II, 182.

* En JAIME VICENS VIVES, op. cit., vol. III, p. 184. Más datos acerca de la legislación de la época sobre los hospedajes, en MOISÉs GARCtA DE LA TORRE, art. cit., pp. 410 y ss.
} 
a fuerza de practicarla, establecía que en las ventas únicamente se ofreciera alimento a las caballerías, y alojamiento y fuego a los huéspedes, con lo que éstos se veían obligados a llevar consigo, si eran gente noble, «cocinero, despensero y repostería», como ocurre a los viajeros cervantinos ${ }^{97}$.

En la primera venta en que se hospeda don Quijote, sirven al hidalgo una cena que, además de evocar los lugares comunes de la tradición folklórica, se parece a la que tuvieron los viajeros cuyos testimonios hemos recogido: «una porción de mal remojado y peor cocido bacallao y un pan tan negro y mugriento como sus armas" ${ }^{98}$. Y ya en tierras de Aragón, camino de Barcelona, el ventero que hospedó a Sancho y a su señor, les asegura que su venta está provista "de las pajaricas del aire, de las aves de la tierra y de los pescados del mar" ${ }^{99}$. Sancho querría huevos con tocino, pero el ventero, igual que en el cuentecillo tradicional, no puede servir tales "gollerías", ya que sólo dispone de:

...dos uñas de vaca que parecen manos de ternera, o dos manos de ternera que parecen uñas de vaca [...] cocidas, con sus garbanzos, cebollas y tocino ${ }^{100}$.

También encontramos en el Quijote el motivo del ventero ladrón emparentado con Caco, que circulaba profusamente en la tradición

${ }^{97}$ Don Quijote (II, 59), OC, II, 808. Francesco Guicciardini ya había experimentado en 1512 la costumbre de no dar al viajero nada más que alojamiento y pienso para los caballos (MOISÉs GARCIA DE LA TORRE, art. cit., p. 418); y años más tarde, según explicaba A. Jouvin: «No hay hospederías en los pueblos ni en los caminos; únicamente casas que llaman posadas o ventas, donde se proporciona el cubierto, porque no es alli permitido el vender víveres, si no es vino; es necesario mandar a buscar por la población y que lo arreglen en esa clase de casas» (José GaRcfa MERCADAL, op. cit., vol. II, p. 751). Peter Heylin comentaba por su parte en 1621: $\alpha$ Las fondas y ventas de este país están muy mal acondicionadas: hasta tal punto que la mayoría de los que no quieren irse a la cama sin cenar, llevan su propia comida en el arzón, y personas de rango, su cama también. Así es de pobre y de misera la recepción que dan en estos sitios" (PATRICIA SHAW FAIRMAN, op. cit., p. 70). Thomas Williams observó durante su viaje, en 1680: «Por toda Castilla y Aragón no se encuentra nada de comer o beber en las posadas, sino que hay que mandar traer de fuera de la posada vino, pan y carne, que ellos, bien lo sabe Dios, preparan de manera muy pobrex (ibid., p. 79). Y algo parecido ocurre en Cataluña, según Robert Bargrave: «Me hospedé en una población pequeña llamada Tárrega, y aquí experimenté por primera vez la costumbre en estas zonas (que en Aragón es ley) de que los viajeros no deben recibir nada del hostelero, salvo pienso para los caballos y la cama; de manera que (por enfermo, mojado o cansado que esté) el viajero ha de comprar su propia comida en otro lado, ya sea tarde ya sea temprano, y agradecerle al posadero que se la guise» (ibtd., p. 77).

98 Don Quijote (I, 2), OC, II, 314.

99 Ibid. (II, 59), OC, II, 807.

100 Ibfd. (II, 59), OC, II, 808. 
oral, y que se ajustaba, según parece, a un modelo real. Recordemos, en efecto, que en la venta donde el hidalgo fue armado caballero, el huésped:

...era andaluz, y de los de la Playa de Sanlúcar, no menos ladrón que Caco, ni menos maleante que estudiante o paje ${ }^{101}$.

Y según explica al futuro caballero, había frecuentado los más conocidos parajes de la picaresca:

...y otras diversas partes, donde había ejercitado la ligereza de sus pies y sutileza de sus manos, haciendo muchos tuertos, recuestando muchas viudas, deshaciendo algunas doncellas $\mathbf{y}$ enganaando a algunos pupilos $\mathbf{y}$. finalmente, dándose a conocer por cuantas audiencias y tribunales hay casi en toda España; y que, a lo último, se había venido a recoger a aquel su castillo, donde vivía con su hacienda y con las ajenas ${ }^{102}$.

Y en fin, tampoco falta en las páginas de nuestro novelista el personaje de la moza de hostal, ansiosa de satisfacer todos los deseos de sus visitantes. En la Posada del Sevillano de Toledo, por ejemplo, en que vive la ilustre fregona, la Gallega y la Argüello acosaban con requiebros nocturnos a sus jóvenes huéspedes ${ }^{103}$. En la primera venta que visitó don Quijote, el caballero andante pudo ver "a la puerta dos mujeres mozas, destas que llaman del partido, las cuales iban a Sevilla con unos harrieros" ${ }^{104}$; y en la de Juan Palomeque, Maritornes y el arriero habían acordado:

...que aquella noche se refocilarian juntos, y ella le había dado su palabra de que, en estando sosegados los huéspedes y durmiendo sus amos. le iría a buscar y satisfacerle el gusto en cuanto le mandase. Y cuentase desta buena moza que jamás dio semejantes palabras que no las cumpliese, aunque las diese en un monte y sin testigo alguno, porque presumía muy de hidalga; y no tenía por afrenta estar en aquel ejercicio de servir en la venta ${ }^{105}$.

Maritornes encarna de manera muy exacta, además, la ínfima condición de ese erotismo directo y sórdido que se prodiga en las ventas y mesones. Recordemos que la moza era:

$101 \mathrm{Ibld}$. (I, 2), OC, II, 314. Véase, a propósito de este personaje, J. M. BERNARDETE, «El ventero andaluz en el Quijote», Revista Hispánica Moderna, XXXIV, 1968, pp. $140-158$.

${ }_{102}$ Don Quijote (I, 3), OC, II, 315. Aquí recoge Cervantes de pasada un cuentecillo tradicional, que aparece en Melchor de Santa Cruz y otros: el ladrón se recoge en la venta, igual que el santo en la soledad de la ermita, para seguir robando en hábito de ventero. Véase MONIOUE Joly, op. cit., pp. 384 y ss.

103 Novelas ejemplares, OC, II, 186 y ss.

104 Don Quijote (I, 2), OC, II, 313.

105 Ibid. (I, 16), OC, I, 363. 
...ancha de cara, llana de cogote, de nariz roma, del un ojo tuerta y del otro no muy sana. Verdad es que la gallardía del cuerpo suplía las demás faltas: no tenía siete palmos de los pies a la cabeza, y las espaldas, que algún tanto le cargaban, la hacían mirar al suelo más de lo que ella quisiera ${ }^{106}$.

Su camisa "era de harpillera", "Traía en las muñecas unas cuentas de vidrio", los cabellos "en alguna manera tiraban a crines", y el aliento le "olía a ensalada fiambre y trasnochada" ${ }^{107}$ : cualidades que parecen ser comunes a muchas mozas que sirven en las ventas, según se deduce del testimonio de Mme. d'Aulnoy, quien recuerda que en tales lugares:

Todas las mujeres van desmelenadas; se las tomaría por bacantes. Llevan collares de vidrio, cuyas cuentas son tan gordas como nueces; dan cinco o seis vueltas a su cuello y sirven para ocultar la piel más puerca del mundo ${ }^{108}$.

Los datos que hemos expuesto hasta ahora hacen patente, una vez más, lo mucho que Cervantes debe a la tradición literaria oral de su época, que conocía bien, y de la que supo aprovecharse de forma original: es parte de su tributo a la filosofía vulgar, encerrada a menudo en las majadas y cabañas de los pastores ${ }^{109}$. Nuestro autor no se limita, sin embargo, a trasvasar en estado bruto los cuentecillos o refranes que corren de boca en boca, sino que selecciona y aprovecha de manera personal esos variados materiales que la tradición oral le ofrece, de manera que el cuentecillo, hábilmente unido a otras fuentes literarias de tipo culto, queda entretejido en el relato sin que se advierta el límite entre ambos, o bien sirve como embrión de unas situaciones y unos personajes que sólo dan impresión de autenticidad cuando reciben el aliento de la realidad viva, observada y retratada con rigor: un ventero socarrón y una pareja «del partido», una manta de anjeo tundido y una estera de enea, una porción de mal remojado bacalao, o un labriego manteado por cuatro pícaros, bastan para que el esqueleto del cuentecillo oral se convierta en estupendo retablo de la realidad coetánea, y en una de las primeras manifestaciones de realismo dentro de la literatura universal ${ }^{110}$.

Hablar de realismo en el caso de Cervantes no está fuera de lugar, sobre todo si tenemos en cuenta que este término no debe identificarse:

\footnotetext{
106 Ibid. (I, 16), OC, I, 362.

107 Ibld. (I, 16), OC, I, 364.

108 JoSÉ GARCIA MERCADAL, op. cit., vol. II, p. 952.

109 Don Quijote (I, 50), OC, II, 561.

110 Véase ERICH AUERBACH, Mímesis, La representación de la realidad en la literatura occidental, México, FCE, 1950, capitulo XIV.
} 
...con ninguna escuela o tendencia en concreto, inclusive la que recibi 6 este nombre por antonomasia en el siglo XIX, sino con esa otra constante mimética del arte que mira y reproduce creativamente la realidad ' 11 .

Ya Aristóteles definió la poesía como una imitación verosímil de las acciones humanas ${ }^{112}$, y distinguía la labor del historiador de la del poeta en estos términos:

...la diferencia está en que uno dice lo que ha sucedido, y el otro, lo que podria suceder. Por eso también la poesía es más filosófica y elevada que la historia; pues la poesía dice más bien lo general, y la historia, lo particular. Es general a qué tipo de hombres les ocurre decir o hacer tales o cuales cosas verosímil o necesariamente, que es a lo que tiende la poesfa, aunque luego ponga nombres a los personajes; y particular, qué hizo o qué le sucedió a Alcibiades "13.

El arte de Cervantes ${ }^{114}$ se halla sin embargo más cerca de la formulación de El Pinciano, para quien el objeto de la poesía:

...no es la mentira, que sería coincidir con la Sophística, ni la Historia, que sería tomar la materia al histórico; y, no siendo historia, porque toca fábulas, ni mentira, porque toca historia, tiene por objeto el verisímil que todo lo abraça ${ }^{11}$.

$\mathrm{Y}$, en efecto, lo que diferencia la obra cervantina de la ficción anterior no es la mímesis a la que aludía la teoría literaria clásica, sino la aparición de ese nuevo género realista que llamamos novela, en el que se integran la ejemplaridad y universalidad de la verdad poética, y la representación verosímil de gentes particulares en sus circunstancias particulares ${ }^{116}$, y en que el creador imita las acciones humanas, según el precepto aristotélico, prestando especial atención a la individualización de los personajes y a la descripción verosímil de su entorno ${ }^{117}$.

in Darfo Villanueva, Teorias del realismo literario, Madrid, Instituto de España-Espasa Calpe, 1992, p. 25.

112 *...el poeta debe ser artífice de fábulas más que de versos, ya que es poeta por la imitación, e imita las acciones* (ARISTOTELES, Poética, edic, trilíngue de Valentín García Yebra, Madrid, Gredos, 1974, p. 160). «...no corresponde al poeta decir lo que ha sucedido, sino lo que podría suceder, esto es, lo posible según la verosimilitud o la necesidad» (ibid., p. 157).

113 Ibid., p. 158.

114 Para la teorla literaria cervantina, y especialmente para los aspectos que aquí tratamos, véase AMÉrico CASTRO, El pensamiento de Cervantes, Barcelona, Noguer, 1972, pp. 27 y ss.; y EDWARD C. RILEY, Teoría de la novela en Cervantes, Madrid, Taurus, 1971, capítulo V.

i1s Alonso LÓPEZ PINCIANo, Philosophta Antigua Poética, edic. de Alfredo Carballo Picazo, Madrid, CSIC, Biblioteca de Antiguos Libros Hispanos, 1973, 3 vols., vol. I, p. 220.

116 IAN WaTt, The Rise of the Novel, London, Penguin Books, 1972, p. 16.

117 Ibid., p. 19. 
De esta forma, y tal como observaba don Quijote, "las historias fingidas tanto tienen de buenas y de deleitables cuanto se llegan a la verdad o la semejanza della" "118; sin olvidar que esa verdad literaria depende ante todo de la "adecuación entre la experiencia del lector y la imagen artística que contemplan ${ }^{119}$, y como ha indicado Darío Villanueva, es el resultado de una intencionalidad ${ }^{120}$ : la del receptor, que al atribuir un sentido al texto, comprueba también su veracidad, poniéndolo en relación con una realidad extratextual previamente conocida, en la que se incluye "no sólo el universo empírico, social e histórico, sino también el artístico y literarion ${ }^{121}$; y en lo que aquí nos concierne, el relato será por consiguiente realista en la medida en que sus lectores hayan proyectado sobre los personajes y las situaciones de la narración, no sólo el estereotipo folklórico del ventero embaucador y la venta inhabitable, sino también un conjunto de experiencias previamente conocidas o vividas, incluso de manera personal, en circunstancias análogas.

El tema tan traído y llevado del realismo cervantino nos lleva de la mano a un problema de mayor envergadura, que quisiéramos dilucidar antes de concluir: la obra literaria no es un espejo en el que se refleje de manera totalmente fidedigna el mundo circundante; hay en ella justificación o rechazo, defensa o negación, inversión idealizadora o deformación grotesca, sublimación o parodia; las imágenes que nos ofrece han sido construidas a partir de datos previamente seleccionados por el autor, y no nos proporcionan por consiguiente una visión objetiva de la realidad social, sino sólo una representación imaginaria de la misma; y a esta relación imaginaria del hombre con sus condiciones de existencia reales, junto a la representación a menudo invertida y falseada que de ella resulta, y a la que comúnmente llamamos ideología ${ }^{122}$, hay que achacar el fenómeno de refracción que sufre la realidad cuando es vista a través del prisma de la ficción literaria.

La ideología es, en efecto, un sistema de ideas, valores, normas y juicios, que configura y orienta el pensamiento y la actividad práctica de un determinado grupo social, cuya visión del mundo logra hacer explícita y coherente ${ }^{123}$, y tiene por ello una existencia co-

118 Don Quijote (II, 62), OC, II, 825.

119 FERNANDO LAZARO CARRETER, «El realismo como concepto crítico-literario*, en Estudios de poética. (La obra en st), Madrid, Taurus, 1976, p. 136.

120 Dario VillanueVa, op. cit., pp. 85 y ss.

121 Ibid., p. 118.

122 LOUIS ALTHUSSER, Ideologia y aparatos ideológicos de Estado, Buenos Aires, Nueva Visión, 1974, p. 52.

123 LuCIEN GoldMANN, El hombre y lo absoluto. «Le Dieu caché, Barcelona, Ediciones Península, 1968, pp. 28-29; y CARLOS ReIs, Para una semiótica de la ideologia, Madrid, Taurus, 1987, p, 21. 
lectiva y un carácter eminentemente funcional: sirve a los grupos hegemónicos para justificar su propia situación de privilegio y reforzar el sometimiento de los grupos subalternos, o proporciona a estos, aunque en menor medida, los instrumentos morales y teóricos para la crítica y la eventual transformación del orden social existente ${ }^{124}$, lo cual explica esa imagen deformada y parcial de la realidad que la ideología nos ofrece.

El individuo hereda, asimila y hace suyo, a menudo de forma inconsciente, ese conjunto de representaciones y reglas de acción social, y difícilmente es capaz de abolirlas o modificarlas por sí solo, por lo que el significado de la obra literaria, en el que esa ideología se expresa, excede a menudo el ámbito de la personalidad intelectual de un escritor aislado, para servir de vehículo a concepciones de carácter colectivo, situándonos frente a lo que Goldmann denominó sujeto plural de la creación literaria ${ }^{125}$.

Debido a su carácter significativo y a su función social, la ideología actúa en el seno de la colectividad como un código ${ }^{126}$, cuyos signos se muestran en mensajes de índole muy diversa - jurídicos, políticos, filosóficos o publicitarios-, y en un amplio abanico de sistemas de comunicación no lingüísticos, como el vestido, las costumbres, las ceremonias de carácter social y el arte. La literatura, en cuanto sirve de vehículo a la ideología, funciona por su parte, según ha señalado Carlos Reis ${ }^{127}$, como una semiótica connotativa: el texto literario es el soporte significante de un significado ideológico connotativo, que se superpone al sentido denotativo del propio mensaje, y que tiene por ello un carácter global, precario y encubierto, lo cual explica las dificultades con que topa cualquier intento de precisar y definir la significación ideológica de las creaciones literarias.

La literatura, en lugar de exponer, presupone unos determinados contenidos ideológicos ${ }^{128}$, de tal forma que bajo la superficie

124 LUCIEN GOLDMANN, «El estructuralismo genético en Sociología de la Literaturaw, en ROLAND BARTHES y otros, Literatura y Sociedad. Problemas de metodología en sociologia de la literatura, Barcelona, Ediciones Martínez Roca, 1969, p. 210.

125 LUCIEN GoldmanN, «Le sujet de la création culturelle», en Critique sociologique et critique psychanalitique, Bruxelles, Editions de l'Institut de Sociologie, Université Libre de Bruxelles, 1970, pp. 193-211. Véase también JUAN IGNACio FERRERAS, «Le problème du sujet collectif en Littérature», en Actes. Picaresque Espagnole. Etudes Sociocritiques, Montpellier, Université Paul Valery, Centre d'Etudes Sociocritiques, 1976, pp. 57-67.

126 Véase UMBerTo Eco, Tratado de semiótica general, Barcelona, Lumen, 1985, pp. 457 y ss.; y CARLOS REIS, op. cit., pp. 50 y ss.

127 CARLOS REIS, Fundamentos y técnicas del análisis literario, Madrid, Gredos, 1981 , pp. 341 y ss.

128 JUAN OlEzA, «La literatura, signo ideológico*, en Jose ROMERA CASTILlo (coord.), La literatura como signo, Madrid, Playor, 1981, pp. 204 y ss. 
textual hay un mensaje implícito y sobreentendido, que sólo muestra su verdadera eficacia cuando el lector lo descodifica, a menudo de forma inconsciente, convirtiéndolo así en la manifestación discursiva de un código ideológico determinado. El crítico, sin embargo, no puede conformarse con esta exégesis intuitiva, y ha de abordar una operación explicativa mucho más compleja, si quiere apresar y determinar de manera exacta la significación de una obra: debe formular de forma explícita el mensaje subliminal, silenciado y sobreentendido tras la apariencia externa del texto, y hacer visibles así los signos del código ideológico, que sólo se manifiestan de manera huidiza y difusa en el plano de los significados. Para ello es necesario traspasar los estrechos límites de la lectura textual, como luego veremos, poner al descubierto la compleja red de relaciones intertextuales en que la obra se inserta, y concebir la creación literaria como uun proceso de absorción y transformación más o menos radical de múltiples textos que se proyectan (continuados o rechazados) en la superficie de un texto literario particular" ${ }^{129}$.

Volviendo de nuevo al tema que nos ocupa, la alusión a la incomodidad y penuria de los alojamientos, tan frecuente en las crónicas de los viajeros y en la ficción literaria, parece ser un dato objetivo que resume con bastante fidelidad las exiguas condiciones de vida del momento; la insistente aparición de la figura del ventero, y su valoración claramente peyorativa en la literatura de la época, con todo lo que pueda tener de verdad el tópico, nos parece motivada, en cambio, por una actitud mental de carácter colectivo, y remite, creemos, a un determinado código ideológico y a una cierta concepción de la realidad social cristalizada en él.

De lo expuesto hasta el momento se deduce de manera evidente el parentesco que une a la novela picaresca y otras producciones cultas con la tradición folklórica; y lo más sencillo es pensar que estos autores desarrollaron un motivo literario - la bellaquería del ventero- nacido entre aquellas gentes situadas en lo más bajo de la escala social -arrieros, labriegos, mozos de mulas-, que por motivos laborales se veían obligados a frecuentar las ventas y los mesones, y que expresarían a través del refrán y del cuentecillo mordaz su resentimiento contra el individuo que, tras sustraerse a las servidumbres y penurias del grupo social subalterno, ha logrado enriquecerse a costa de los desposeídos que forzosamente han de tratar con él.

Los cuentos de venteros reúnen, por tanto, los requisitos propios de la literatura popular ${ }^{130}$ (son textos orales, inestables y

129 CARLOS REIS, Fundamentos y técnicas, p. 108.

130 MAURICIO MOLHO, op. cit., pp. 11-33. 
transformables, funcionales, impersonales y colectivos), y cumplen además, vistos desde esta óptica, la función que Mauricio Molho ha asignado a un gran número de relatos folklóricos: la de una catártica compensación ofrecida entre risas a aquellas gentes que, por su condición social, se hallan alejadas para siempre del poder y la riqueza ${ }^{131}$. Y aun podría añadirse, para corroborar esta tesis, la función igualmente consoladora de aquellos cuentecillos en que, mediante un proceso de subversión muy frecuente en el folklore, el explotador se convierte en víctima: nos referimos a las historietas protagonizadas por estudiantes o pícaros que engañan con algún ardid ingenioso al tabernero avaro o a la mesonera incauta ${ }^{132}$, y mediante los cuales el auditorio, compuesto por gentes humildes, protagonizaría en su imaginación una chusca venganza inofensiva y gozosa.

Aunque plausible, la interpretación anterior nos parece insuficiente, ya que no aclara por qué los autores cultos adoptan repetidamente ciertos motivos de la tradición oral y no otros, cuál era el significado último de la elección, y qué sentido tenían para ellos los personajes de tales cuentecillos.

Para hallar una respuesta válida a tales cuestiones, debemos recordar ante todo que el cuento folklórico, cuando abandona el circuito de la literatura popular, y es incorporado a la obra escrita de un autor individual, pierde sus rasgos distintivos y se desfolkloriza, al quedar inserto en el circuito de la literatura culta ${ }^{133}$. En tales casos, su función subversiva y liberadora desaparece también, y el texto adquiere un nuevo sentido, derivado del código ideológico propio de aquel sector de la sociedad - generalmente el grupo social hegemónico- al que el escritor pertenece, o con el que se halla intelectual y afectivamente identificado.

Situados en esta nueva perspectiva, nos parece que la presencia del ventero ladrón en la literatura culta del Siglo de Oro sólo guarda una relación genética muy remota con ese resentimiento de los trajineros y gentes humildes que hacian noche en las ventas, y que tal motivo debe ser interpretado, por el contrario, salvo algunas excepciones ${ }^{134}$, a la luz de la doctrina aristocrática que tachaba de

\footnotetext{
131 Ibid., p. 334.

132 Véase MAXIme Chevalier, Cuentos folklóricos españoles, números 168, 177 y 178 .

133 MaUricio Molho, op. cit., pp. 14 y ss, y pássim.

134 Como ha señalado Monioue Joly (op. cit., p. 363), Mateo Alemán es sin duda la excepción más destacada, ya que su crítica, inspirada en un espiritu que podriamos calificar de pre-burgués, apunta a las dificultades y obstáculos que los malos hospedajes representan para el desarrollo de las actividades comerciales: *Cesan los tratos por temor de venteros y mesoneros, que por mal servicio llevan
} 
infames las actividades profesionales como el comercio, la artesanía, y todas las relacionadas con los hospedajes y la hostelería.

En efecto, la creencia en el origen natural de las desigualdades sociales, y la convicción de que el talante moral del individuo es consecuencia de su linaje, fueron dos pilares básicos de la ideología nobiliaria en la Europa del Antiguo Régimen ${ }^{135}$ : el noble, por designio divino y ley humana, ha nacido para gobernar, y además del patrimonio de sus antepasados, ha heredado en la sangre la superioridad moral y las cualidades necesarias para cumplir tal cometido. Por este motivo, comentaba Castillo de Bovadilla, "de los nobles siempre se presume cualquier cosa buena y virtuosa” ${ }^{136}$, ya que, según explica otro autor:

Todos engendran su semejante. El hombre engendra hombre; el bueno engendra bueno; no es lo último preciso, pero es ordinario. En el trigo, para estimarle, se atiende mucho al campo que le produce. En los hombres, para estimarlos, se atiende mucho a la sangre de que descienden ${ }^{137}$.

De los villanos, en cambio, sólo pueden esperarse acciones reprobables, puesto que «la sangre ruin engendra pensamientos ruines» ${ }^{138}$, y los «bajos pensamientos no arguyen menos que humilde linaje" ${ }^{139}$.

De la doctrina que hemos expuesto nace, como consecuencia lógica, la tacha de deshonor que pesa sobre la mayoría de las actividades propias del tercer estado, y la idea de que «la luz, y la claridad de la sangre, obscurece el que exercita oficios mecánicos" ${ }^{140}$ : los plebeyos, en efecto, carecen de elevación moral porque han venido al mundo para servir y obedecer, y según explicaba Benito Guardiola:

buena paga, robando públicamente. [...] Pues, prometo que la reformación de los caminos, puentes y ventas, no es lo que requería menos cuidado que las muy graves, por el comercio y trato* (MATEo Alemán, Guzmán de Alfarache, en La novela picaresca española, edic. cit., vol. I, p. 370).

135 Véase ARLETE JouANNA, Ordre social. Mythes et hiérarchies dans la France $d u$ xvle siècle, Paris, Hachette, 1977, pp. 15 y ss.; y Jose Antonio Maravall, Poder, honor y élites en el siglo XVII, Madrid, Siglo XXI, 1979, pp. 41 y ss.

136 Jerónimo CASTILlo de Bovadilla, Política para corregidores y señores de vassallos, Madrid, 1597, 2 vols., vol. I, p. 93.

137 JUAN DE ZABALETA, Errores celebrados [1553], edic. de David Hershberg, Madrid, Espasa Calpe, Clásicos castellanos, 1972, pp. 133-134.

138 JUAN DE ZABALETA, El dia de fiesta por la tarde [1660], edic. de José María Díez Borque, Madrid, CUPSA, 1977, p. 89.

139 MATEO ALEMAN, Guzmán de Alfarache, en La novela picaresca española, edic. cit., vol. I, p. 494.

i40 JERÓNIMO DE LA CRUZ, Defensa de los estatvtos y noblezas españolas, Zaragoza, 1637, p. 4. 
...son dichos gente vil, por quanto tratan en officios viles y muy abatidos [...], por ser ellos de sí mesmos, y también porque los que se inclinan a algunos dellos suele ser gente ruyn por la mayor parte ${ }^{141}$.

El plebeyo, si es tratante o mercader, desconoce además el imperativo ético y la generosidad de los nobles, y guiado únicamente por el afán de lucro, suele ser, en opinión de Mercado, "muy amante de su dinero, y codicioso del ajeno: vicio, que a los hombres de buen ingenio dio siempre muy en rostro" ${ }^{142}$; con lo cual su oficio deviene fácilmente latrocinio y usura ${ }^{143}$.

Quien está al frente de una venta o un mesón, ha hecho de la virtud tradicional de la hospitalidad aristocrática un motivo de lucro y granjería, y su actividad representa la irrupción de un espíritu de tipo mercantilista en un esquema ideológico y social de corte tradicional ${ }^{144}$. Los venteros son además siervos, oficiales, usureros y mercaderes, todo al mismo tiempo, y si a ello se añade el linaje morisco que la tradición les achacaba ${ }^{145}$, no es extraño que en su persona aparezcan reunidos, según la opinión común, todos los requisitos de la infamia, ya que, en efecto:

...llaman viles e iliberales [comenta Gutiérrez de los Ríos parafraseando el De officiis de Cicerón] a los oficios y artes, en que se incurre en odio de

141 FRAY JUAN BEnito Guardiola, Tratado de nobleza y de los títulos y ditados que oy dia tienen los varones claros y grandes de España, Madrid, 1595, fols. 8-9.

142 TOMÁS DE MERCADO, Suma de tratos y contratos [1571], edic. de Restituto Sierra Bravo, Madrid, Editora Nacional, 1975, p. 133.

143 Cfr.: *...conciencia en mercader es como virgo en cotorrera, que se vende sin haberse» (FRANCISCO DE QUEVEDO, Historia de la vida del Buscón, en Obras completas, edic. cit., vol. I, p. 353). «Pero lo que más me espantó fue ver los cuerpos de dos o tres mercaderes que se habían calzado las almas al revés, y tenían todos los cinco sentidos en las uñas de la mano derechan (FRANCISCO DE QUEVEDO, El sueño del juicio final, ibid., p. 140), «El mercader hurta, dando a usura, pasando el justo y riguroso precio y asentando en su libro la deuda que por ventura estará tres veces pagada» (CARLOS GARCIA, La desordenada codicia de los bienes ajenos, en la novela picaresca española, edic. cit., vol. II, p. 114).

144 Véase Monique Joly, op. cit., pp, 368-370.

145 Ibid., pp. 380 y ss. Recuérdese el pasaje de Quevedo ya citado: «El ventero era morisco y ladrón, que en mi vida vi perro y gato juntos con la paz de aquel dían (FrancIsco DE QUEVEDo, Historia de la vida del Buscón, en Obras completas, edic. cit., vol. I, p. 331). Ruiz de Alarcón incluyó esta canción mordaz en Las paredes oyen: «Venta de Viveros, / ¡dichoso sitio, / si el ventero es cristiano, / y es moro el vino!» (JUAN RUIZ DE ALARCón, La verdad sospechosa. Las paredes oyen, edición, prólogo y notas de Alfonso Reyes, Madrid, Espasa-Calpe, col. Clásicos Castellanos, 1967, p. 198). Y en cuanto a las implicaciones castizas de La picara Justina, y el linaje morisco de la protagonista, véase MARCel Bataillon, Pícaros y picaresca, Madrid, Taurus, 1982, pp. 115 y ss. El tópico no parece sin embargo muy ajustado a la realidad: entre las profesiones de los moriscos más frecuentemente mencionadas por los documentos de la época, no suele aparecer la de ventero: Véase ANTONIO DOMINGUEz ORTIZ y BERNARd VINCENT, Historia de los moriscos. Vida y tragedia de una minoria, Madrid, Revista de Occidente, 1978, pp. 109 y ss. 
las gentes, como son los portazgueros y logreros. Llaman viles [...] a todos los que venden o alquilan sus personas, senuicio, y libertad por algún salario o sueldo, a quien el dinero les es premio de su seruidumbre, como son todos los que siruen. Dizen también que se han de tener por viles los que compran de los mercaderes para reuender luego: porque estos no pueden ganar, sino es mintiendo mucho. Llaman viles a todos los oficiales que se ocupan en artes suzias: porque en sus obradores no puede auer cosa noble, ni liberal. Tienen por viles a las artes y oficios, que son causa de gula y de deleyte y sustento de pecados, los quales son (como Tulio dize) todo género de figones, hostaleros, pasteleros, pescadores, carnizeros, los que hazen y venden perfumes, y olores, bolteadores, y otros desta suerte ${ }^{146}$.

Todo lo cual tenía también importantes consecuencias de tipo práctico, ya que el mesonero, como cualquier otro individuo que ejerciese alguno de los llamados oficios infames, no sólo quedaba mancillado socialmente y privado de la honra, sino que era además víctima de medidas discriminatorias que le impedían acceder a numerosas instituciones de carácter nobiliario, profesional o religioso. En los estatutos de la Orden de Santiago, por ejemplo, se negaba el hábito a todo aquel que hubiera ejercido oficios viles y mecánicos, como son los de:

...platero, o pintor, que lo tengan por oficio, bordador, canteros, mesoneros, taberneros, escriuanos, que no sean Secretarios del Rey, o de qualquier persona Real; procuradores públicos, o otros oficios semejantes a estos, o inferiores dellos, como son sastres, y otros semejantes, que viuen por el trabajo de sus manos ${ }^{147}$.

Y no se trata de una excepción, ya que en 1593, Tomás Gutiérrez, vecino de Córdoba y amigo personal de Cervantes, solicitó

146 GASPAR GUTIÉRREZ DE LOS RIOS, Noticia general para la estimación de las artes, y de la manera en que se conocen las liberales de las que son mecánicas, Madrid, 1600 , pp. 52-53. Más datos sobre el descrédito de la artesanía y el comercio, y sus consecuencias legales en la España del Antiguo Régimen, pueden verse en ANTONIO DOMfNGUEZ ORTIZ, «Notas sobre la consideración social del trabajo manual y el comercio en el Antiguo Régimen», Revista de Trabajo, VII, 7-8, 1945, pp. 673-681; ALFONSO FIGUEROA Y MELGAR, «Los prejuicios nobiliarios contra el trabajo y el comercio en la España del Antiguo Régimen», Cuadernos de Investigación Histórica, 3, 1979, pp, 415-436; JoSÉ ANTONIO MARAVALL, «Trabajo y exclusión. El trabajador manual en el sistema social de la primera modernidad*, en Estudios de historia del pensamiento español. Serie segunda. La época del Renacimiento, Madrid, Ediciones Cultura Hispánica, 1984, pp. 363-392; PERE Molas, La burguesía mercantil en la España del Antiguo Régimen, Madrid, Cátedra, 1985, capítulos V y VI; y JAVIER GUILlamón ÁlVAREZ, Honor y honra en la España del siglo XVIII, Madrid, Universidad Complutense, 1980. Sobre el problema de la marginación discriminatoria en general durante el Siglo de Oro, véase el conjunto de estudios reunidos y presentados por AUGUSTIN REDONDO, Les problemes de l'exclusion en Espagne (XVI'-XVIr siecles), Paris, Publications de la Sorbonne, 1983.

147 FRANCISCO RUIZ DE VERGARA, Regla y establecimientos nueuos de la Orden y Cauallería del Glorioso Apostol Santiago, Madrid, 1655, título I, cap. 5. ${ }^{\circ}$, fol. 57. 
ingresar en la Cofradía del Santísimo Sacramento de dicha ciudad, y su petición fue denegada alegando que el solicitante:

...ha sido público representante con autores de comedias, y él mismo ha sido autor de comedias, y de presente tiene casa de posada, mesón, y da camas ${ }^{148}$.

La infamia del mesonero se prolongó durante largo tiempo: todavía en el siglo XVIII, Fernández de Mesa opinaba que se debía elegir para tal oficio a hombres de bien, ya que:

Uno de los daños mayores, que se ha experimentado en los Mesoneros, es la poca fidelidad, y propensión al hurto, a que les incita la ocasión de averse de fiar a su cuidado ${ }^{149}$.

En 1748, el gremio de los pasamaneros de Toledo estableció que los aprendices fuesen hijos de cristianos viejos, no castigados por la Inquisición, ni de oficios "como son cortadores, zapateros, mesoneros y otros de igual baxeza" ${ }^{150}$; y, en la misma época, los mercaderes de lienzos de Barcelona admitían únicamente a los aspirantes que:

...no hayan exercido oficio vil, ni otro que en el Principado de Cataluña se tenga por bajo, como son el de mesonero, pregonero, cortante y otros semejantes ${ }^{151}$.

La mala fama de ventas y mesones, aguijada por la animadversión popular, había quedado plasmada en refranes, anécdotas y cuentecillos orales, según vimos, y de ellos se sirvieron a menudo los escritores cultos. El retrato peyorativo de los hospedajes en la novela y el entremés, obedece, sin embargo, a esas otras motivaciones ideológicas diametralmente opuestas que acabamos de ilustrar: sobre la figura literaria del ventero se proyecta, más que el recelo contra sus posibles hurtos, todo un haz de prejuicios aristocráticos, visibles en los ejemplos que hemos citado, que convertían en latrocinio e infamia las actividades profesionales situadas fuera de la órbita nobiliaria, de todo lo cual se burla Cervantes en la novela de El coloquio de los perros, cuando la dueña de la posada en que la Colindres y el alguacil saquean a los incautos, se queja ante la justicia alegando que:

\footnotetext{
148 LUIS Astrana MARIN, Vida ejemplar y heroica de Miguel de Cervantes Saavedra, Madrid, Editorial Reus, 1948-1958, 7 vols., vol. V, p. 66.

149 ThOMAS MANUEL FerNANDEZ DE MESA, Tratado legal y politico de caminos públicos y posadas, Valencia, 1755-56, p. 25.

150 Citado por PERE MOLAS, op. cit., pp. 197-198.

151 Ibid., p. 198.
} 
...yo soy mujer honrada y tengo un marido con su carta de ejecutoria, y con a perpenan rei de memoria, con sus colgadores de plomo.

A lo que el Teniente replica:

Hermana camarera, yo quiero creer que vuestro marido tiene carta de hidalguía con que vos me confeséis que es hidalgo mesonero ${ }^{152}$.

$\mathrm{Y}$ es que en éste, como en otros aspectos, Cervantes es un escritor de actitudes originales y calidad excepcional, pues, aunque su obra incluya la obligada referencia a la bellaquería de los venteros y a la incomodidad de los hospedajes, en ella adivinamos un verdadero acto de subversión artística y doctrinal, consistente en presentar en sus relatos venteros diligentes y honrados, y venteras honestas y caritativas, negando así cualquier vigencia a los lugares comunes. En la venta de Juan Palomeque, por ejemplo, el cura pidió al ventero:

...que les aderezasen de comer de lo que en la venta hubiese, y el huésped, con esperanza de mejor paga, con diligencia les aderezó una razonable comida ${ }^{153}$.

Y en otra ocasión:

...por orden de los que venían con Don Fernando había el Ventero puesto diligencia y cuidado en aderezarles de cenar lo mejor que a él le fue posible ${ }^{154}$.

Recordemos también cómo en Las dos doncellas, el huésped del mesón de Castilblanco aparece retratado como un «hombre diligente y de recato", y la huéspeda como una mujer "caritativa» ${ }^{155}$. La moza Maritornes, que sirve en la venta de Juan Palomeque, es compasiva, y obsequia a Sancho con un jarro de vino que paga de su propia bolsa, porque "tenía unas sombras y lejos de cristiana" ${ }^{156}$. El propio Juan Palomeque también afirma con ironía «que, aunque ventero, todavía soy cristiano" ${ }^{157}$; y durante la primera estancia en la venta, la mujer del dueño no era:

...de la condición que suelen tener las de semejante trato, porque naturalmente era caritativa y se dolía de las calamidades de sus prójimos ${ }^{158}$,

152 Novelas ejemplares, $O C$, II, 276. Con ironía semejante explica Guzmán de Alfarache que su suegro, «aunque mesonero, era un buen hombre», y todos sus familiares «de los buenos de la montaña, hidalgos como el Cid, salvo que por desgracias y pobreza vinieron en aquel trato* (MATEO ALEMAN, Guzmán de Alfarache, en La novela picaresca española, edic. cit., vol. I, p. 675).

153 Don Quijote (I, 32), OC, II, 458.

154 Ibid. (I, 37), OC, II, 496-497.

155 Novelas ejemplares, OC, II, 209-210.

156 Don Quijote (I, 17), OC, II, 370.

157 Ibid. (I, 32), OC, II, 461.

158 Ibtd. (I, 16), OC, II, 361-362. 
Con lo cual Cervantes no sólo rechaza el tópico literario que estimaba forzosa la ecuación ventero = caco, a la vez que acrecienta la verosimilitud de sus relatos, sino que contradice además los dogmas del código ideológico aristocrático, en el que la maldad de los individuos de baja sangre se juzgaba irremediable. Y así, frente «al vano discurso del vulgo, casi siempre engañado» ${ }^{159}$, que admite sin más este tipo de descalificaciones, nuestro autor desliga el ser individual y la condición social de los hombres, y estima lo que estos valen por sí mismos, con independencia de su linaje; porque, como afirma repetidamente nuestro autor:

...la sangre se hereda, y la virtud se aquista y la virtud vale por si sola lo que la sangre no vale ${ }^{160}$.

\section{JAVIER SALAZAR RINCONN}

159 Los trabajos de Persiles y Sigismunda (II, 20), OC, II, 974.

160 Don Quijote (II, 42), OC, II, 741. 